\title{
Bathyglycinde profunda (Hartman \& Fauchald) (Polychaeta, Goniadidae): new combination
}

\author{
Alexandra Elaine Rizzo \& Antonia Cecília Zacagnini Amaral
}

Departamento de Zoologia, Instituto de Biologia, Universidade Estadual de Campinas, Caixa Postal 6109, 13083-970 Campinas, São Paulo, Brasil. E-mail: aerizzo@hotmail.com; ceamaral@unicamp.br

\begin{abstract}
Goniadid polychaetes belonging to the genus Bathyglycinde Fauchald, 1972 were collected during the REVIZEE Program/South Score/Benthos on the outer shelf and continental slope off the south-southeastern coast of Brazil. This genus is recorded for the first time from Brazilian waters. A new combination for the species Glycinde profunda Hartman \& Fauchald, 1971 is proposed, and the species is illustrated. This species was originally assigned to the genus Glycinde Müller, 1858, but the conspicuous proboscideal papillae and the simple capillary notochaetae without knob are typical of Bathyglycinde. Bathyglycinde profunda comb. nov. differs from other congeneric species mainly in having all chaetigers with single pre- and postchaetal lamellae, proboscideal papillae in Area I and 32-41 uniramous chaetigers. This is the first member of the genus found in less than abyssal depths. A key to the species of Bathyglycinde is provided.
\end{abstract}

KEY WORDS. Brazil, Glycinde, new combination, outer continental slope.

RESUMO. Poliquetas goniadídeos pertencentes a Bathyglycinde Fauchald, 1972 foram coletados durante o programa REVIZEE/Score Sul/Bentos “Avaliação do Potencial Sustentável dos Recursos Vivos na Zona Econômica Exclusiva" na plataforma externa e talude continental sul-sudeste do Brasil. Originalmente esta espécie estava em Glycinde Müller, 1858, mas as papilas proboscideais e cerdas notopodiais capilares não geniculadas são características de Bathyglycinde. Bathyglycinde profunda (Hartman \& Fauchald, 1971) comb. nov. difere das outras espécies do gênero por ter uma única lamela pré- e uma pós-setal em todos os setígeros, papilas proboscideais na área I e 32 34 setígeros unirremes. Uma chave de identificação para as espécies de Bathyglycinde é fornecida. Este é o primeiro registro de uma espécie do gênero em águas não abissais.

PALAVRAS CHAVE. Brasil, Glycinde, nova combinação, plataforma externa.

Of the nine genera belonging to the family Goniadidae, only Bathyglycinde Fauchald, 1972 and Glycinde Müller, 1858 have the proboscis covered by longitudinal rows of long or short chitinous papillae. The main difference between these two genera lies in the presence of simple capillary notochaetae in Bathyglycinde, opposed to the presence of notochaetae that are knobbed or falcate hooded hooks in Glycinde (Fauchald, 1977). The proboscis was divided into Areas I to VI (numbered dorsoventrally) by HarTMAn (1950: 45-47, text-fig. 2), to facilitate comprehension and establish a standard. Area I, the middorsal, is composed of one or more rows of tiny papillae. Areas IIVI are paired and oriented dorso-ventrally. Area II includes a large part of the proboscis, and its long papillae are uni- or bidentate, arranged in rows numbered from II1 to II6. Area III has 1 to 8 rows of small papillae. Area IV is composed of rows of papillae that are usually dorso-ventrally flattened and arranged in zigzags. Area V has long or short papillae, whereas area VI is generally smooth. The proboscideal papillae have a subapical or apical pore containing anterior ceraceous and posterior mucous cells (BANTZ \& Michel 1971, 1972) that are connected by a channel to the ciliated pore (HARTMAN 1950, Sмiтh et al. 1995). The function of the cilia is still unknown, but probably is related to protection of the channel, preventing its obstruction. Because of their morphological diversity and different arrangements, the structures of the proboscideal papillae have great taxonomic value in goniadids. However, these structures have rarely been described and illustrated.

Herein, the species Glycinde profunda Hartman \& Fauchald, 1971 is transferred to the genus Bathyglycinde, emend the diagnosis of the latter genus, and improve the species description. Additionally, a comparison table and a key for the species of Bathyglycinde is provided.

\section{MATERIAL AND METHODS}

Specimens of goniadids were collected during the program REVIZEE/South Score/Benthos sampling cruises of the $\mathrm{R} / \mathrm{V}$ "W. BESNARD", on the outer shelf and continental slope off Brazil from Ilha Grande Bay, Rio de Janeiro State $\left(23^{\circ} 43.60^{\prime} \mathrm{S}\right.$, 
$\left.42^{\circ} 06.50^{\prime} \mathrm{W}\right)$ to Tramandaí, Rio Grande do Sul State $\left(29^{\circ}\right.$ $\left.14.672^{\prime} \mathrm{S}, 47^{\circ} 50.669^{\prime} \mathrm{W}\right)$; water depths were 60 to $808 \mathrm{~m}$. The samples were collected with van Veen and box-corer grabs and a dredge. The polychaetes were sorted from the sediment, washed, fixed with $4 \%$ formalin, stored in $70 \%$ alcohol, and identified.

Measurements and line drawings were made using Zeiss optical microscopy and stereomicroscopy. The material examined was deposited in the Museu de Historia Natural of the Universidade Estadual de Campinas (UNICAMP), in the Polychaeta Collection (MHN-BPO).

\section{RESULTS AND DISCUSSION}

\section{Bathyglycinde Fauchald, 1972}

Type species: Bathyglycinde mexicana Fauchald, 1972

Diagnosis: Smooth or weakly annulated prostomium. Proboscideal papillae of many types, long or short, arranged dorso-ventrally in six areas. One pair of macrognaths and a variable number of micrognaths. Chevron absent. Single or bifid prechaetal lamellae in anterior and posterior chaetigers, or only in posterior ones. Capillary notochaetae with serrated distal article; long spiniger neurochaetae with shaft end smooth or fringed.

Remarks: FaUCHALD (1972) described Bathyglycinde to include species with: a) smooth prostomium, b) two or three kinds of proboscideal organs [papillae], absent from Areas I and VI, c) two macrognaths, d) micrognaths present in varying number, e) chevrons absent, f) notopodium with slender capillary chaetae and finely dentate edges, and g) bifid prechaetal lamellae only on posterior chaetigers or also on anterior ones. However, it is necessary to enlarge the genus diagnosis to include species of Bathyglycinde with the prostomium weakly annulated, proboscideal papillae present in Area I, single prechaetal lamellae in biramous chaetigers instead of only bifid, and neurochaetae with shaft ends fringed instead of only smooth. The main difference between Glycinde and Bathyglycinde is that the former has sub-distally protuberant and distally slender notochaetae instead of capillary ones (FAUCHALD 1977).

Bathyglycinde contained four species: the type species Bathyglycinde mexicana Fauchald, 1972; Bathyglycinde cedroensis Fauchald, 1972 and Bathyglycinde lindbergi (Uschakov, 1955); this last species was transferred to Bathyglycinde by FAUCHALD (1972). All species described in this genus until now are from the Pacific Ocean: B. mexicana and B. cedroensis from the surroundings of the Gulf of California, and $B$. lindbergi from the Sea of Okhotsk. According to Petribone (1970), Glycinde sibogana Augener \& Pettibone, 1970, with 29 uniramous chaetigers, may be synonymous with $B$. lindbergi. However, in his brief description of G. lindbergi, Uschaкov (1955) did not mention the number of uniramous chaetigers. The fourth species, Bathyglycinde profunda from off the Bermudas and Surinam, has a nonannulated prostomium, 40-41 uniramous chaetigers, notopodia with capillary chaetae and undivided parapodial lamellae. All of these species were collected from abyssal waters $( \pm 2000 \mathrm{~m}$ depth) and described from a small number of individuals.

\section{Key to species of Bathyglycinde}

1. Biramous chaetigers with single neuropodial prechaetal lamellae; 32-41 uniramous chaetigers

Bathyglycinde profunda

$1^{\prime}$. Biramous chaetigers with bifid neuropodial prechaetal lamellae; 21-26 uniramous chaetigers .. 2

2. Uniramous chaetigers with bifid prechaetal lamellae; 21-22 uniramous chaetigers Bathyglycinde mexicana

2 '. Uniramous chaetigers with single prechaetal lamellae, more than 22 chaetigers

\section{3}

3. Bifid prechaetal neuropodial lamella with superior end more elongated than inferior; postchaetal neuropodial lamella more elongated than prechaetal; 25-26 uniramous chaetigers Bathyglycinde cedroensis

3'. Bifid prechaetal neuropodial lamella with superior and inferior ends almost the same length; postchaetal neuropodial lamella the same length as the prechaetal lamella; [number of uniramous chaetigers not mentioned in the original description] Bathyglycinde lindbergi

\section{Bathyglycinde profunda (Hartman \& Fauchald, 1971) comb. nov. \\ Figs 1-21, Tab. I}

Glycinde profunda Hartman \& Fauchald, 1971: 74-76, pl. 4, figs c-e.

Glycinde sp. Hartman, 1965: 99.

Material examined: 9 specimens: St. 6689, 2708.90'S, $46^{\circ} 37.70^{\prime} \mathrm{W}, 500 \mathrm{~m}, 18 . \mathrm{I} .1998$ (MHN-BPO-AR52, $1 \mathrm{spec}$ ); St. $6743,23^{\circ} 55.40^{\prime} \mathrm{S}, 42^{\circ} 47.60^{\prime} \mathrm{W}, 508 \mathrm{~m}, 15 . \mathrm{II} .1998$ (MHN-BPOAR560, 1 spec.); St. $6749,2^{\circ} 44.20^{\prime} \mathrm{S}, 42^{\circ} 29.80^{\prime} \mathrm{W}, 325 \mathrm{~m}$, 16.II.1998 (MHN-BPO-AR283, 1 spec.); St. 6752, 2343.60'S, $42^{\circ} 06.50^{\prime} \mathrm{W}, 502 \mathrm{~m}, 16 . \mathrm{II} .1998$ (MHN-BPO-AR599, 1 spec.); St. 6777, 26 $51.76^{\prime} \mathrm{S}, 46^{\circ} 18.47^{\prime} \mathrm{W}, 500 \mathrm{~m}, 13 . \mathrm{III} .1998$ (MHN-BPOAR11, 1 spec.); 13.III.1998 (MHN-BPO-AR09, 1 spec.); St. 6783, $27^{\circ} 09.90^{\prime} \mathrm{S}, 46^{\circ} 52.83^{\prime} \mathrm{W}, 350 \mathrm{~m}, 14 . \mathrm{III} .1998$ (MHN-BPO-AR339, 2 spec.); St. $6811,29^{\circ} 14.672^{\prime} \mathrm{S}, 47^{\circ} 50.669^{\prime} \mathrm{W}, 506 \mathrm{~m}, 22 . \mathrm{III} .1998$ (MHN-BPO-AR331, 1 spec.).

Description: Only one complete specimen with 67 chaetigers, $19.0 \mathrm{~mm}$ length and $0.26 \mathrm{~mm}$ width (chaetiger 10); incomplete specimens up to $14 \mathrm{~mm}$ in length, and widths of 0.1-0.34 mm. Coloration relatively uniform; yellowish body with brownish pigment on dorsal and ventral regions and on parapodia. Dorsum with quadrate to rectangular segmental patches, separated medially by narrow stripes and segmental lines, dorsal unpigmented longitudinal bands without pigmentation; ventrum with three rows of similar patches on the dorsum, the median patch broadest. Prostomium unpigmented or with light pigmentation, antennae and interchaetiger re- 


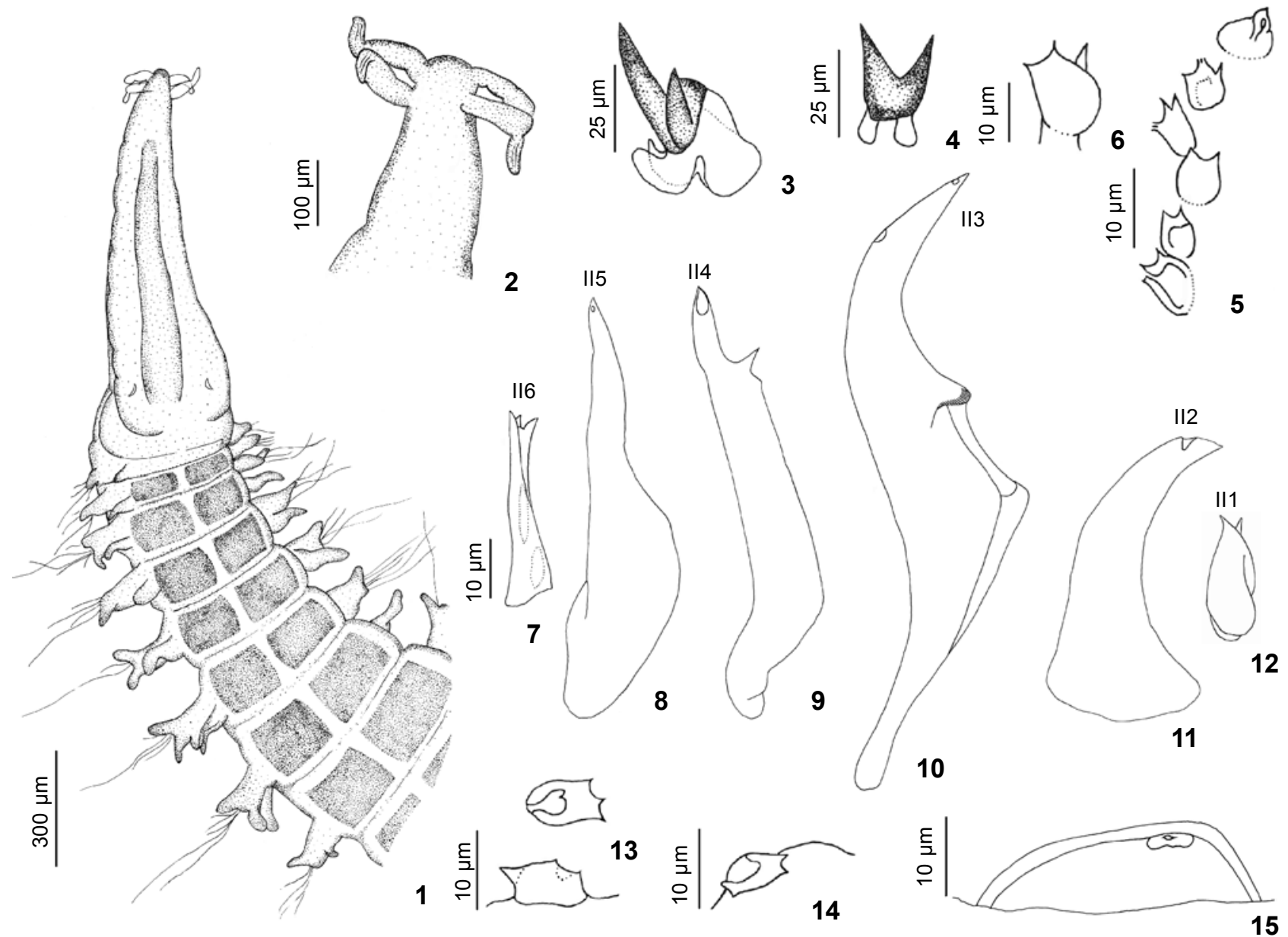

Figures 1-15. Bathyglycinde profunda comb. nov.: (1) anterior region, left latero-dorsal view; (2) antennae, frontal view; (3) macrognath with two cuspids; (4) H-shaped micrognath; (5) row of proposcideal papillae of Area I; (6) detail of the papilla of Area I, lateral view; (7) papilla from Area II6; (8) Area II5; (9) Area II4; (10) Area II3; (11) Area II2; (12) Area II1; (13) tricuspid papilla from Area III, dorsal view (above), lateral view (below); (14) bicuspid papilla from Area IV, dorsal view; (15) flattened papilla from Area V, on proboscideal base.

gion without pigment. Prostomium longer than wide, apparently smooth, with about 10 weakly demarcated rings (Fig. 1); two dorso-lateral longitudinal ridges may be present. Bi-articulate antennae; basal article twice the size of the distal article (Fig. 2). Eyes not seen. Small nuchal organ, half-moon-shaped, located dorso-laterally in the basal ring. Proboscis bears two macrognaths, each one with two or three cuspids (Fig. 3) and four H-shaped micrognaths (Fig. 4). Latero-ventrally macrognaths; latero-dorsally to dorsally micrognaths. Proboscideal papillae of many types: Area I - a row of short papillae, rounded basally, bidentate and with a subapical pore (Figs 5-6); Area II - six rows of long papillae with a subapical pore (II1-II6; Figs 712): II1 and II6 - short, rounded basally, bidentate (Figs 7, 12); II2-II3, II5 - long, unidentate, subapical pore (Figs 8, 10-11); II3 with prominent anterior-median face (Fig. 10); II4 - bidentate with pore in superior fang (Fig. 9); Area III - a row of small, dorso-ventrally flattened papillae, arranged in zigzag and with a large central pore; tridentate anterior and rounded posterior end (Fig. 13); Area IV - a row of short rectangular papillae, dorso-ventrally flattened, a large central pore; bidentate anterior and rounded posterior end (Fig. 14); Area V - shorter papillae, obscure, dorsally flattened and ventrally extended, with apical pore arranged on proboscidial base (Fig. 15); Area VI - smooth. Papillae in areas III-V arranged in transverse rows. Shorter medium and anterior parapodia, about one-third of its body width; posterior parapodia about same length as body in this region. A midventral groove extends throughout its body length. First chaetiger with parapodial lobe, dorsal and ventral cirri and chaetae. Uniramous parapodia with a subtriangular to digitiform prechaetal lamella and a subtriangular 

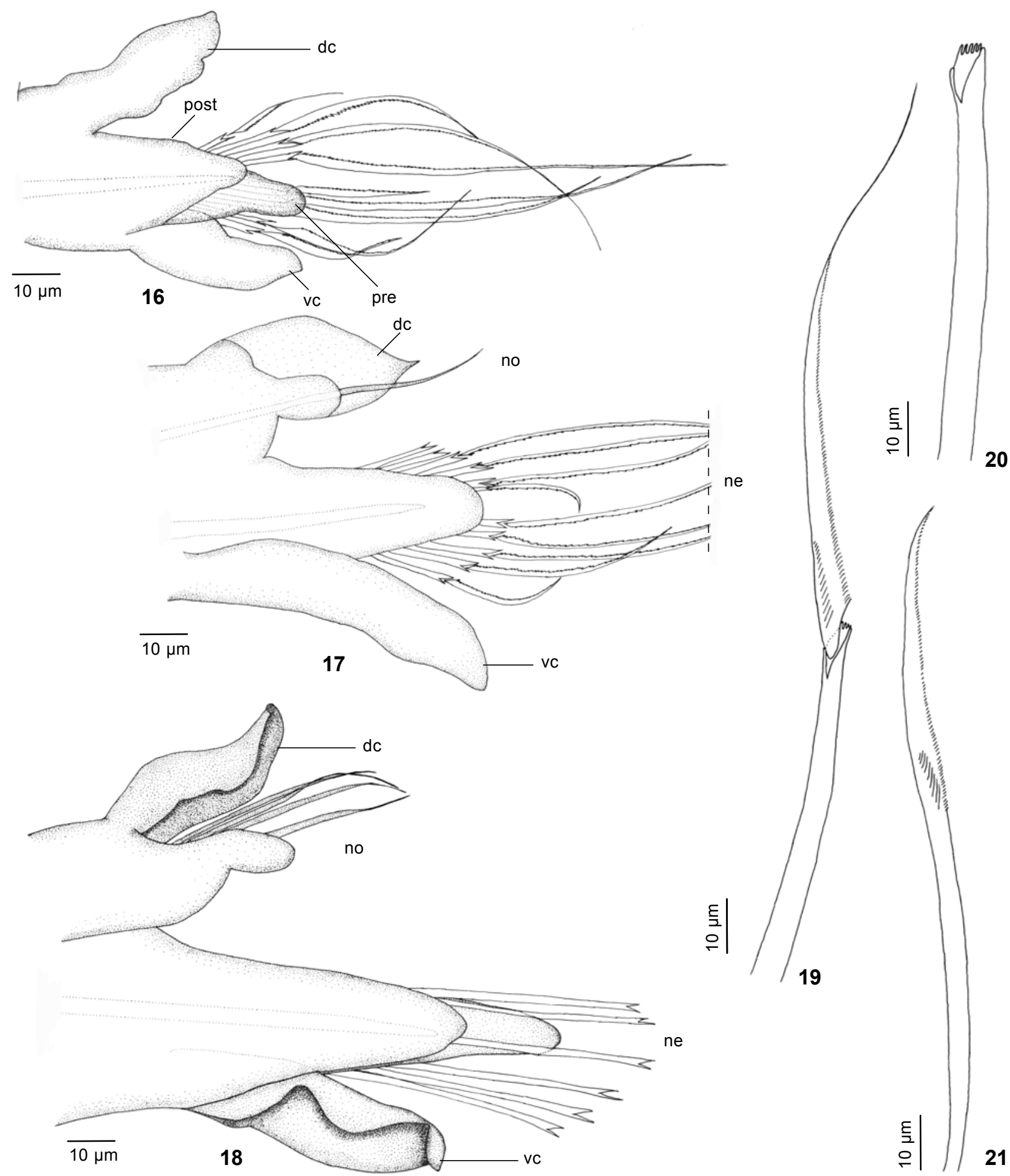

21

Figures 16-21. Bathyglycinde profunda comb. nov.: (16) chaetiger 10, posterior view; (17) chaetiger 33, anterior view; (18) chaetiger 40, posterior view, distal article omitted; (19) outer spiniger neurochaeta; (20) spiniger neurochaeta with distal end fringed, distal article omitted; (21) capillary notochaeta. (dc) Dorsal cirrus, (no) notopodium, (ne) neuropodium, (post) postchaetal lamella, (pre) prechaetal lamella, (vc) ventral cirrus.

Revista Brasileira de Zoologia 21 (4): 937-942, dezembro 2004 
Table I. Comparison between species of Bathyglycinde described in the literature and Bathyglycinde profunda comb. nov. (NM) Not mentioned, (A) area.

\begin{tabular}{|c|c|c|c|c|}
\hline Species & B. mexicana & B. cedroensis & B. lindbergi & B. profunda \\
\hline Distribution & $\begin{array}{l}\text { Farallon Basin, Gulf of } \\
\text { California }\end{array}$ & $\begin{array}{l}\text { Cedros Island, Baja California } \\
\text { and Cabo Corrientes }\end{array}$ & Okhotsk Sea & $\begin{array}{l}\text { Off Suriname and Rio } \\
\text { de Janeiro to Rio } \\
\text { Grande do Sul, Brazil }\end{array}$ \\
\hline Prostomium & Smooth & Smooth & NM & $\begin{array}{l}\text { Annulated weakly, with } \\
\pm 10 \text { rings }\end{array}$ \\
\hline $\begin{array}{l}\text { Macrognaths (number of } \\
\text { cuspid) }\end{array}$ & $2(3-4)$ & 2 & $2(2)$ & $2(2-3)$ \\
\hline $\begin{array}{l}\text { Micrognaths (number of } \\
\text { cuspid) }\end{array}$ & $6(2)$ & $+5(\mathrm{NM})$ & $\begin{array}{l}7(2-3) \text { (?each micrognath } \\
\text { with } 1 \text { or } 2 \text { pieces) }\end{array}$ & $4(2)$ \\
\hline \multicolumn{5}{|l|}{ Proboscideal papillae } \\
\hline Al & Absent & Absent & NM & Fig. 6 \\
\hline All & Tall and slender & Tall and slender & NM & Figs $7-12$ \\
\hline Alll & $\begin{array}{l}\text { Small and solid, } \\
\text { slightly recurved }\end{array}$ & Large and soft & NM & Fig. 13 \\
\hline AIV & Idem Alll & NM & NM & Fig. 14 \\
\hline $\mathrm{AV}$ & Idem AllI & Short and recurved & NM & Fig. 15 \\
\hline $\begin{array}{l}\text { Number of uniramous } \\
\text { chaetigers }\end{array}$ & $21-22$ & $25-26$ & NM & $32-41$ \\
\hline \multicolumn{5}{|c|}{ Neuropodial lamellae (uniramous chaetigers) } \\
\hline Prechaetal & $\begin{array}{l}\text { Bifid; pointed superior } \\
\text { end, rounded inferior }\end{array}$ & Single, pointed & $\begin{array}{l}\text { Single, elongated and } \\
\text { pointed }\end{array}$ & $\begin{array}{l}\text { Single, sub-triangular } \\
\text { to digitiform }\end{array}$ \\
\hline Postchaetal (single) & Digitiform & Elongated and pointed & Elongated and pointed & Sub-triangular \\
\hline \multicolumn{5}{|c|}{ Neuropodial lamellae (biramous chaetigers) } \\
\hline Prechaetal & $\begin{array}{l}\text { Bifid; superior and } \\
\text { inferior pointed }\end{array}$ & $\begin{array}{l}\text { Bifid; superior more elongated } \\
\text { and pointed than inferior }\end{array}$ & $\begin{array}{l}\text { Bifid; elongated and } \\
\text { Pointed, superior and } \\
\text { inferior with the same } \\
\text { length }\end{array}$ & $\begin{array}{l}\text { Single, sub-triangular } \\
\text { to digitiform }\end{array}$ \\
\hline Postchaetal (single) & Digitiform & $\begin{array}{l}\text { Blunt and more elongated } \\
\text { than prechaetal }\end{array}$ & $\begin{array}{l}\text { Almost the same length of } \\
\text { the prechaetal }\end{array}$ & Sub-triangular \\
\hline $\begin{array}{l}\text { Notopodial lamellae } \\
\text { (birramous chaetigers) }\end{array}$ & $\begin{array}{l}\text { Rounded lobe. } \\
\text { Digitiform prechaetal; } \\
\text { short and rounded } \\
\text { postchaetal }\end{array}$ & $\begin{array}{l}\text { Rounded lobe. Digitiform } \\
\text { prechaetal; postchaetal similar } \\
\text { to the acicular lobe }\end{array}$ & $\begin{array}{l}\text { Alongated and pointed } \\
\text { prechaetal; rounded } \\
\text { postchaetal }\end{array}$ & $\begin{array}{l}\text { Digitiform prechaetal; } \\
\text { rounded postchaetal }\end{array}$ \\
\hline \multicolumn{5}{|l|}{ Cirrus } \\
\hline Dorsal & $\begin{array}{l}\text { Recurved with a } \\
\text { distinct knob on the } \\
\text { ventral edge }\end{array}$ & Foliaceous & Triangular & Foliaceous \\
\hline Ventral & $\begin{array}{l}\text { Thick, with slender tip } \\
\text { (uniramous) and blunt } \\
\text { (biramous) }\end{array}$ & Large and foliaceous & Digitiform with pointed tip & Conical to foliaceous \\
\hline
\end{tabular}

postchaetal lamella; postchaetal lamella about one-third as long as prechaetal lamella (Fig. 16). Foliaceous dorsal cirrus about as long as postchaetal lamella. Conical to foliaceous ventral cirrus, located parallel or ventro-posteriorly to parapodium and about as long as prechaetal lamella. 32-34 uniramous chaetigers. Parapodial change abrupt. Chaetiger which precedes the parapodial change has the notopodial lobe fused to the dorsal cirrus; notopodial chaetae and aciculum present (Fig. 17). Biramous parapodia have digitiform prechaetal lamella; short, rounded postchaetal lamella one-third length of prechaetal lamella. Neuropodia of uniramous and biramous chaetigers similar, with the biramous chaetigers slightly more elongated (Fig. 18). Both notopodia and neuropodia with embedded acicula. 1-5 notopodial chaetae simple, capillary, with the distal end very fine and the edge serrated (Fig. 21); 7-12 neuropodial chaetae spiniger, very long, possibly natatory, with distal end fringed 
(Fig. 19) and distal article finely serrated (Fig. 20). Distal article of the outer chaetae up to twice the length of the inner chaetae. Length of spiniger chaetae from chaetiger 60 - outer chaeta: $165 \mu \mathrm{m}$, inner chaeta: $315 \mu \mathrm{m}$. Posterior end with rudimentary chaetigers. Oocytes may be enclosed in the parapodial lobe, beginning with chaetiger 40 (diameter of oocytes 22-65 $\mu \mathrm{m}$ ).

Remarks: Both specimen MHN-BPO-AR339 and the type material of Bathyglycinde profunda were examined by Dr. Markus Böggemann (pers. com.), who informed us that they are the same species. Bathyglycinde profunda comb. nov. differs from other species of the genus in having: a) the pre- and postchaetal lamella single, in all parapodia; b) proboscideal papillae in Area I; c) proboscideal papillae, mainly in Areas III and IV, different from the others; and d) 32-41 uniramous chaetigers (Tab. I). The specimens of Glycinde profunda examined by HARTMAN \& FAUCHALD (1971) have single pre- and postchaetal lamellae on the anterior and posterior chaetigers. Moreover, they are similar to the Brazilian specimens in relation to color pattern, body measurements, reduced number of micrognaths, shape of the dorsal and ventral cirri, capillary notochaetae and inner spiniger neurochaetae longer than the outer ones. The main differences between the two populations consist of the number of uniramous chaetigers, i.e., 32-34 in Brazilian specimens and about 40 in those from the equatorial region; and the shape of the prostomium, smooth in equatorial specimens and weakly ringed in Brazilian ones. The proboscideal papillae were not described in detail in the original description of $G$. profunda. It is known that in G. profunda the papillae of Area II are larger and conspicuously falcate and some are unidentate distally, while others are bidentate; those of Areas I and III-VI have inconspicuous or absent pharyngeal processes.

Bathymetric distribution: The species was first collected at depths between 2862 and 5023 m (Hartman \& Fauchald 1971). The specimens here examined occurred at depths between 325 and $508 \mathrm{~m}$.

Geographic distribution: Atlantic Ocean - off Bermuda and Surinam, and off Brazil (Ilha Grande Bay, Rio de Janeiro to Tramandaí, Rio Grande do Sul).

\section{ACKNOWLEDGEMENTS}

This work was supported by the State of São Paulo Research Foundation (FAPESP), as part of the BIOTA/FAPESP The Biodiversity Virtual Institute Program (www.biotasp.org.br). Our thanks to the CNPq (Conselho Nacional de Desenvolvimento Científico e Tecnológico, Process 141504/98-6) and the MMA (Ministério do Meio Ambiente, dos Recursos Hídricos e da Amazônia Legal) for financial support. We appreciate the facilities and assistance of the Departamento de Zoologia, Instituto de Biologia, UNICAMP. We thank Dr. Markus
Böggemann for his valuable comments and suggestions and for examining the Brazilian goniadids; also Giuliana S. Bachiega, for translating the description of Glycinde lindbergi from Russian into Portuguese. We are much indebted to João M.M. Nogueira and to another anonymous referee for their comments. Janet W. Reid revised the English text.

\section{REFERENCES}

Bantz, M. \& C. Michel. 1971. Revêtement cuticulaire de la gaine de la trompe chez Glycera convoluta Keferstein (Annélide Polychète). Histochimie et ultrastructure. Zeitschrift für Zellforschung und mikroskopische Anatomie, Wien, 118: 221-242.

- 1972. Les cellules sensorielles des papilles de la trompe chez Glycera convoluta Keferstein (Annélide Polychète). Anatomie microscopique et ultrastructure. Zeitschrift für Zellforschung und mikroskopische Anatomie, Wien, 134: 351-366.

FAUCHALD, K. 1972. Benthic polychaetous annelids from deep water off western Mexico and adjacent areas in the Eastern Pacific Ocean. Allan Hancock Monographs in Marine Biology, Los Angeles, 7:1-575.

- 1977. The polychaete worms. Definitions and keys to the orders, families and genera. Natural History Museum of Los Angeles County Science Series, Los Angeles, XXVIII+188p.

Hartman, O. 1950. Goniadidae, Glyceridae and Nephtyidae. Allan Hancock Monographs in Marine Biology, Los Angeles, 15 (1): 1-181.

HarTman, O. 1965. Deep water benthic polychaetous annelid of New England to Bermuda and North Atlantic areas. Allan Hancock Foundation, Los Angeles, 28: 1-378.

Hartman, O. \& K. Fauchald. 1971. Deep-water benthic Polychaetous Annelids off New England to Bermuda and other North Atlantic areas. Part II. Allan Hancock Monographs in Marine Biology, Los Angeles, 6: 1-327.

Pettibone, M.H. 1970. Polychaeta Errantia of the SibogaExpedition. Part IV: Some additional polychaetes of the Polynoidae, Hesionidae, Nereidae, Goniadidae, Eunicidae, and Onuphidae, selected as new species by the late Dr. Hermann Augener with remarks on other related species. Siboga-Expeditie Monographie, Leiden, 24: 199-270.

SMith, L.E.; S. Trabanino \& R. Baerwald. 1995. Scanning electron microscopical observations of the proboscideal papillae of Glycinde armigera (Annelida: Polychaeta). Invertebrate Biology, New York, 114 (1): 46-50.

Uschакоv, P.V. 1955. Atlas of the Invertebrates from the Far Eastern Seas of the USSR. Leningrad, Doklady Akademii Nauk SSSR, 445p.

Received in 01.I.2004; accepted in 16.XI.2004.

Revista Brasileira de Zoologia 21 (4): 937-942, dezembro 2004 